\title{
Status of Emission Control Science and Technology in Argentina
}

\author{
Julio E. Vassallo ${ }^{1}$
}

Published online: 1 June 2018

(C) Springer International Publishing AG, part of Springer Nature 2018

With a current population of 44 million inhabitants [1] the Argentine Republic has an automotive fleet of over 14 million vehicles, [2] i.e., a rate of 3.5 inhabitants per vehicle (not taking into account freight transport lorries, passenger transport vehicles, or motorcycles). In the last decade, the number of vehicles in use has practically doubled, having gone from 7.4 million vehicles in 2007 to 14.4 million in 2017 (not taking into account approximately 7 million of motorcycles)

According to our estimates based on [1] and [3], the automotive fleet in Argentina is made up of $65.7 \%$ of light-duty cars (Fig. 1), $29.3 \%$ of utility cars (including sport utility vehicles) and passenger and freight transport vehicles (Fig. 2). Both fleets are equipped with gasoline, diesel, and compressed natural gas engines. The remaining 5\% (about 7000,000 units) corresponds to the fleet of heavy-duty vehicles, equipped with diesel engines exclusively (Fig. 3)

Based on the information available between 1980 and 2017, it is clear that the composition of the entire Argentine automotive fleet by fuel type is $33 \%$ of diesel vehicles, $55 \%$ of gasoline vehicles, and $12 \%$ of vehicles have been converted to CNG.

Moreover, the distribution of each type of fleet by type of fuel between 1980 and 2017 is shown in Figs. 4 and 5.

Argentina started to set limits to vehicle emissions in 1995 through National Decree 779/95, which rules the National Traffic and Road Safety Law No. 24449 (Table 1). The procedures and limits initially adopted for light-duty vehicles took as a reference those specified by the US Code of Federal Regulations (US CFR Title 40 Part 86) in its US Tier 0 phase; whereas, for heavy-duty vehicles they referred to the European Union Directives for EURO I Standards.

Julio E. Vassallo

jvassallo@ina.gob.ar; julio_vassallo@hotmail.com

1 Vehicular Gaseous Emission Control Laboratory (LCEGV), Ministry of Environment and Sustainable Development (MAyDS),

Ezeiza-Cañuelas Highway, Km. 1.62, 1804 Ezeiza, Buenos Aires Province, Argentina
However, in 2002, as the result of a proposal of harmonization of the United Nations Economic Commission for Europe (UNECE) initially agreed in the framework of MERCOSUR, Argentina modified its reference standard for light-duty vehicle emissions by also adopting the European Directives 70/220/CEE and later (Resolution SAyDS 1270/ 2002), thus unifying the certification of emissions of light and heavy vehicles in the same sets of regulations of reference.

From this unification in the same set of regulations, a series of subsequent resolutions (Resolution SAyDS* 1270/2002, $731 / 2005$, and 1464/2014) updated and tightened the maximum emission limits. By incorporating EURO II standards in 2004, EURO III in 2007, EURO IV in 2009, and EURO V in 2015 only for M1** (only with GVW until $2500 \mathrm{~kg}$ ) and in 2016, for the rest of vehicles as detailed in Table 2. This evolution (Figs. 6 and 7) has determined a common path with the European Community in the technology of internal combustion engines, emission control systems, and electronic management development (OBD systems with sensors and actuators) as well as calibrations of the fleet incorporated from 2004 onwards, which currently represents approximately $60 \%$ of the active Argentine vehicle fleet.

Together with the entry of these new emission control technologies for vehicles equipped with gasoline and diesel engines, a series of programs for the incorporation of alternative fuels (mainly compressed natural gas, biodiesel, and bioethanol) were developed in Argentina and in many other countries around the world. These programs were motivated by energy security and sustainability as well as by the strategic economic development of locally available resources and the possibility of applying cleaner and more efficient technologies. One of the first programs began in 1984 and involved the use of compressed natural gas (CNG) which promoted important local regulatory and industrial development. Currently, with a fleet of over 1.7 million vehicles [4] converted to CNG (Fig. 8), Argentina is among the first four countries in the world with the largest fleet of CNG-converted vehicles, but has not yet achieved the initial aim of the program, which 
Cars 1980-2017

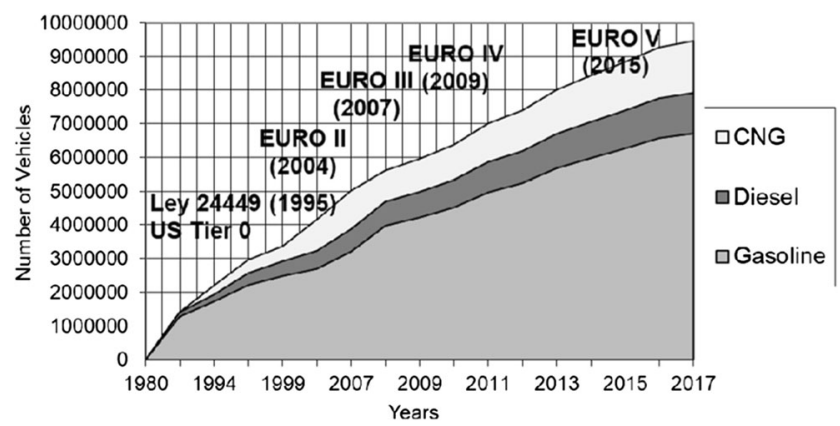

Fig. 1 Cars, 1980-2017

Utilities Vehicles + Passenger and Freight Transport Ligth Duty $<4$ tn $\left(^{*}\right) 1980-2017$

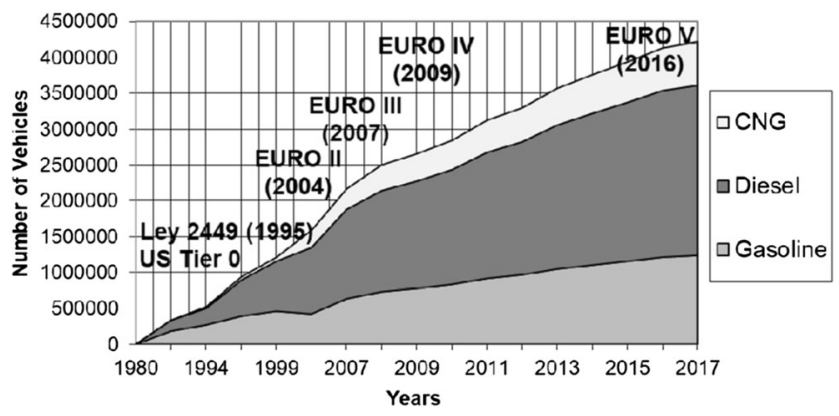

Fig. 2 Utility vehicles + passenger and freight transport light duty $<4$ th (*) 1980-2017. *The division according to the gross vehicle weight (GVW) used by fleet type for "Utilities Vehicles + Passenger and Freight Transport Light Duty $<4$ tn”

\section{Passenger and Freight Trasnport Heavy Duty $>4$ tn (*) 1980-2017}

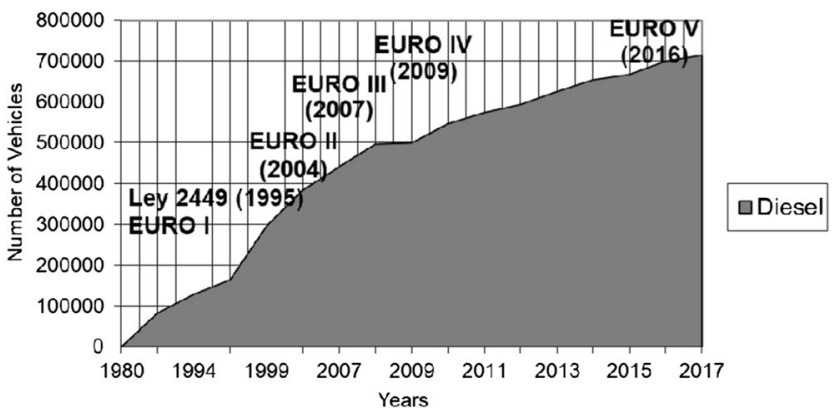

Fig. 3 Passenger and freight transport heavy duty > 4 tn (*), 1980-2017. *The division according to the gross vehicle weight (GVW) used by fleet type for "Passenger and Freight Transport Heavy Duty> 4 tn"does not respond to those adopted by the European Directives (70/200/CEE and later and 88/77/CEE and later, respectively) in which the light duty GWV $<3.5$ tn and heavy duty $>3.5 \mathrm{tn}$, respectively, but the database format available for the automotive fleet in Argentina
Argentina Cars Fleet Distribution, 1980-2017

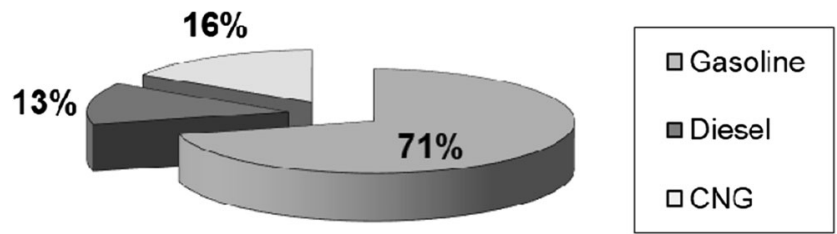

Fig. 4 Argentina cars fleet distribution, 1980-2017

\section{Argentina Distribution of Llght Duty Fleet: Utility Vehicles + Freight and Passenger Transport 1980-2017}

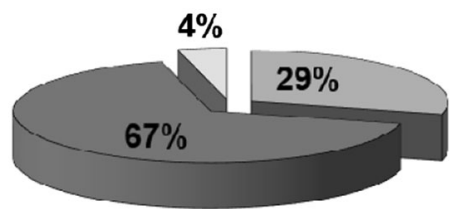

\section{口Gasoline \\ 口Diesel \\ $\square C N G$}

Fig. 5 Argentina distribution of light-duty fleet: utility vehicles + freight and passenger transport, 1980-2017

Table 1 National Decree 779/95, which rules the National Traffic and Road Safety Law No. 24449

Law 24449 Decree 779/95

They approve the new model and the production of $0-\mathrm{km}$ vehicles

- Between 1995 and 2004, US EPA emission limits (according to US CFR 40 Part 86 to US Tier 0 standard) until 2004 for light vehicles and European Directives (88/77/EEC and post to EURO I and II standards) for heavy vehicles (Dec PEN 779/95).

- As of 2004, the EEC regulations for light and heavy duty are established including the following limits for the new designs:

* As of 01/01/2004 EURO II (Resolution SAyDS* 1270/2002) for light-duty vehicles 94/12/EC and heavy-duty vehicles 88/77/EEC. * As of 01/01/2006 EURO III (Resolution SAyDS* 731/2005) for heavy-duty vehicles 99/96/EC.

* As of 01/01/2007 EURO III (Resolution SAyDS* 731/2005) for light-duty vehicles 98/69/EC.

* As of 01/06/2009 EURO IV (Resolution SAyDS* 731/2005)

for light-duty vehicles 98/69/EC and heavy-duty vehicles 2005/55/EC. * As of 01/01/2015 EURO Va (Resolution SAyDS* 1464/2014) Only light-duty vehicles M1** with GWV < $2500 \mathrm{~kg}$ 692/2008/CE. * As of 01/01/2016 EURO Va (Resolution SAyDS* 1464/2014) for light-duty vehicles $\mathrm{M} 1 * *$ with $\mathrm{GWV}>2500 \mathrm{~kg}$ and $\mathrm{N} 1 * *$ (692/2008/EC) and heavy-duty vehicles (2005/55/EC).

*Secretariat of Environment and Sustainable Development (in Spanish Secretaría de Ambiente y Desarrollo Sustentable-SAyDS-) in the present Ministry of Environment and Sustainable Development (in Spanish, Ministerio de Ambiente y Desarrrollo Sustentable de la Nación-MAyDS) **Light Vehicles M1/ N1 and Heavy Vehicles as defined by 715/2008/EC and 692/2008 / EC 
Table 2 Date of entry into force of EURO V and phase out date of EURO III/IV in Argentina

\begin{tabular}{|c|c|c|c|}
\hline $\begin{array}{l}\text { Category of vehicles according to } \\
\text { European directives }\end{array}$ & $\begin{array}{l}\text { Date of entry into force of } \\
\text { EURO V for "New Models" }\end{array}$ & $\begin{array}{l}\text { Date of entry into force of } \\
\text { EURO V for all new vehicles }(0 \mathrm{~km})\end{array}$ & $\begin{array}{l}\text { Phase out date of } \\
\text { EURO IV certification }\end{array}$ \\
\hline $\begin{array}{l}\text { Light-duty M1 } \\
\text { GVW } \leq 2500 \mathrm{~kg}\end{array}$ & 1 January 2015 & 1 January 2017 & 31 December 2016 \\
\hline $\begin{array}{l}\text { Light-duty M1 GVW > } 2500 \mathrm{~kg} \\
\text { and N1 and N1/M1 }\end{array}$ & 1 January 2016 & 1 January 2018 & 31 December 2017 \\
\hline Heavy-duty M2, M3, N2, N3 & 1 January 2016 & 1 January 2018 & $\begin{array}{l}\text { EURO III: } 31 \text { December } 2015 \\
\text { EURO IV: } 31 \text { December } 2017\end{array}$ \\
\hline
\end{tabular}

was the conversion of the heavy-duty fleet. The growth in the fleet of private and commercial light vehicles (both freight and passenger) took place mainly due to the price delta with traditional fuels.

In the last decade, the entry of EURO V standards (Table 2) has suffered several postponements as a result of delays in the programs aiming to improve the environmental quality of traditional commercial fuels (gasoline and diesel). At the present, the higher prices of the better quality fuels (with lower sulfur content according to emission control technologies EUROIV and EUROV) as well as biofuel incorporation programs (current composition of $12 \%$ bioethanol in gasoline and $10 \%$ biodiesel in diesel), promoted as of 2006 by National Law 26093 on the Promotion of Biofuels, have generated a particular local scenario. This new scenario includes the impact of recent technological fraud committed by particular international manufacturer of diesel internal combustion engines as well as the challenges imposed by the issues of energy efficiency improvement and mitigation of global climate change through reduction of $\mathrm{CO} 2$ emissions.

In reference to the real technological composition of the vehicle fleet in use in Argentina, as almost $80 \%$ of the fleet is less than 20 years old [5] most have been subject to emission regulations and standards implemented in Argentina since 1995 (Table 1). In the case of the light vehicles fleet, most gasoline engines (including those converted to $\mathrm{CNG}$ or bi-fuel) have incorporated three-way catalysts or TWC (since

\section{MP Diesel ( $\mathrm{gr} / \mathrm{Km})$ Argentina Standards in Light Duty Vehicles}

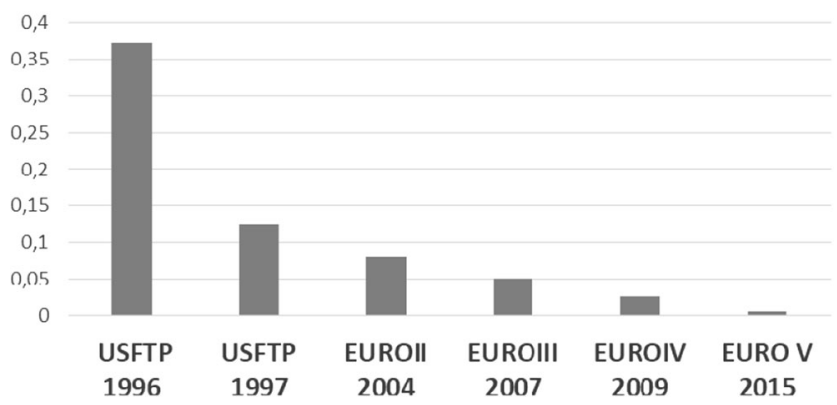

Fig. 6 Diesel engine: evolution in Argentina of particulate material limits (PM) for light-duty passenger vehicles
1999 all gasoline vehicles marketed in Argentina have TWC) and the diesel engines have been equipped with the Diesel oxidation catalysts (DOC) and in some cases exhaust gas recirculation (EGR) systems. The heavy diesel vehicular fleet (Fig. 3) that constitutes the passenger and freight transport is only $5 \%$ of the fleet in use, but consumes more than $50 \%$ of the vehicular fuel, in tons of oil equivalent [4]. This fleet is composed of almost $60 \%$ of EURO III diesel technologies [6], because of the aforementioned delay in the entry of EURO $\mathrm{V}$ technologies (Table 2), while the remaining 40\% (models over 10 years old) are older units with technologies Pre EURO, EURO I, and II.

The use of EURO V technologies in the new models (2015/ 2016) of light and heavy vehicles (more than $10 \%$ of the light fleet and $2 \%$ of the heavy diesel fleet [6] are EURO V) has required the use of the TWC (due to its improved durability, efficiencies, and lower temperature light off) in gasoline engines. Diesel engines have incorporated exhaust aftertreatment systems for NOx removal composed of the following:

- Selective catalytic systems (SCR) with urea injection

- $\quad$ EGR (in a few models mainly light-duty diesel)

On the other hand, the incorporation of particulate filters and oxidation catalyst is currently focused on the light-duty

\section{THC+NOx $(\mathrm{g} / \mathrm{Km})$ \\ Argentina Standards in Light Duty Vehicles}

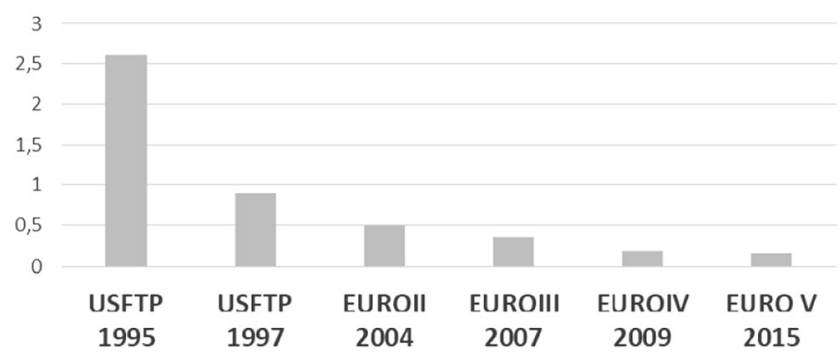

Fig. 7 Otto cycle engine: evolution in Argentina of limits for total hydrocarbons plus nitrogen oxides $(\mathrm{THC}+\mathrm{NOx})$ for light-duty passenger vehicles 


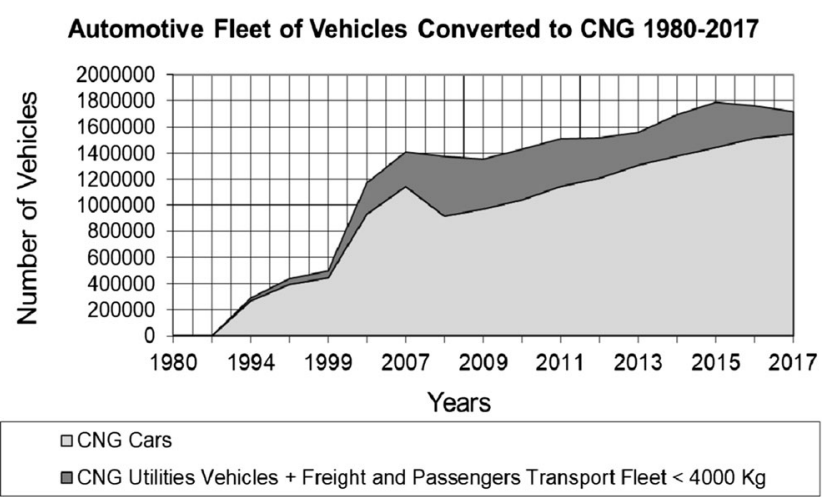

Fig. 8 Automotive fleet of vehicles converted to CNG 1980-2017

diesel (utilities and commercial vehicles) vehicles (GWV $<$ $3500 \mathrm{~kg}$ ), and is projected for heavy-duty vehicles with having EUROVI technologies.

Thus far, there is still no clear and formal implementation date for EURO VI emission Regulations in Argentina. However, taking into account the availability of fuels compatible with EURO VI technologies (Resolution SRH-No. 5/ 2016 Ministry of Energy and Mining), it could be expected that by 2019 , it would be implemented for M1 light vehicles and by 2020 for vehicles N1 and N1/M1 and heavy vehicles (even taking into account the way in which EUROV was implemented).

The installation of a Vehicular Emissions Control Laboratory (Laboratorio de Control de Emisiones Gaseosas Vehiculares or LCEGV-MAyDS) in 1998 (Figs. 9 and 10) and the incorporation of international certification technology for light-duty vehicles in 2005 (according to European Directives and US EPA regulations) have allowed the implementation of emission control technologies into the automotive fleet, according to the EURO II, III, IV, and V standards. It has also enabled the evaluation and characterization of the behavior of the different models commercialized in the Argentine market (automotive headquarter designs assembled

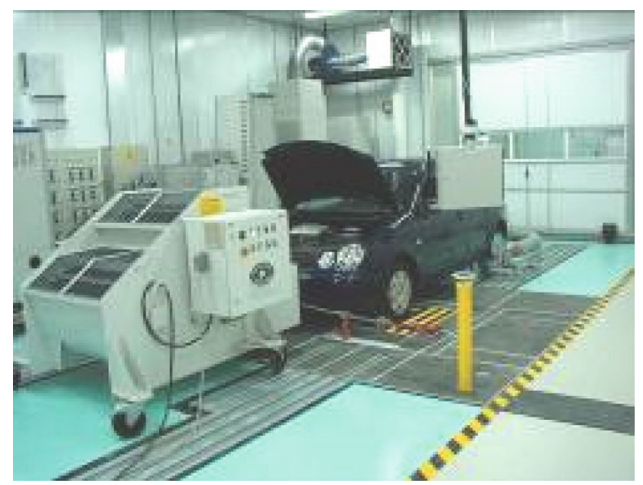

Chassis Dynamometer Room to Exhaust Emission Certification of Light Duty Vehicles

Fig. 9 Chassis dynamometer room to exhaust emission certification of light-duty vehicles

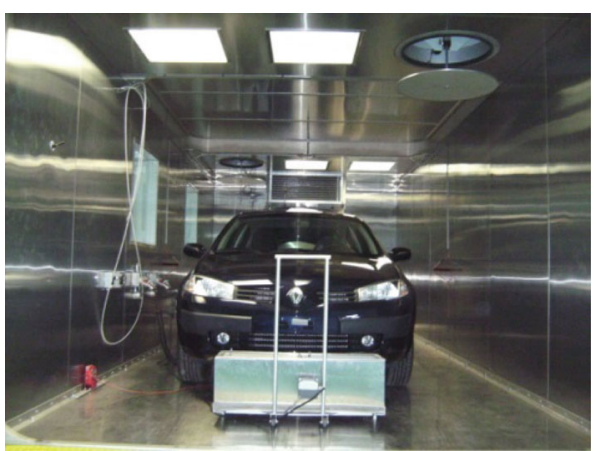

SHED Camera for Certification of Evaporative Emission Certification of Light Duty Vehicles

Fig. 10 SHED camera for certification of evaporative emission certification of light-duty vehicles

in the country or imported vehicles) under specific local conditions (e.g., use of CNG, Biofuels) to interpret through own results and those of international scientific publications, the state of compliance with the standards of vehicular emissions implemented in the country [7].

All Argentine Normative cited from http://www.infoleg. gob.ar/

\section{Compliance with Ethical Standards}

Conflict of Interest The authors declare that they have no competing interests.

\section{References}

1. National Statistics and Census Institute (INDEC) Population Estimates and Projections 2010 - 2040. Demograhic Analysis Series $\mathrm{N}^{\mathrm{o}}$ 35. (Instituto Nacional de Estadísticas y Censo (INDEC) Estimaciones y Proyecciones de Población 2010 - 2040. Serie de Análisis Demográfico No 35. https://ipiec.tierradelfuego.gob.ar/wpcontent/uploads/2013/12/proyeccionesyestimaciones_2010_2040. pdf

2. Statistical Bulletins from the National Directorate of National Registry of Motorvehicles and Chattel Morgages (Boletines Estadísticos de la Dirección Nacional de Registro del Automotor y Créditos Prendarios (DNRPA). http://www.dnrpa.gov.ar/portal_ dnrpa/boletines_estadisticos.php

3. Yearbooks from the Automobile Manufacturers' Association of Argentina (Asociación de Fábricas de Automotores - ADEFA - de Argentina) http://www.adefa.org.ar/en/estadisticas-anuarios

4. Statistical Bulletins from the National Gas Regulation Entity (Boletines Estadísticos del Ente Nacional Regulador del Gas (ENARGAS) http://www.enargas.gov.ar/secciones/gas-naturalcomprimido/estadisticas.php

5. Clarin newspaper, electronic edition June 8, $2017 \mathrm{https}$ ://www.clarin. com/sociedad/vehiculos-15-anos-advierten-riesgosos_0_ rylQ7VDf-.html

6. Presentation of the Argentine Federation of Business Entities of Freight Transport (Federación Argentina de Entidades Empresarias del Autotransporte de Carga - FADEEAC) at the Latin American Workshop on Green Freight Programs, 27-29 June 2017 Buenos 
Aires, Argentina. Organized by the Ministry of Transport, the Ministry of Energy and Mining, and the Ministry of Environment and sustainable development, in conjunction with the United States Environmental Protection Agency (EPA), The International Council on Clean Transportation (ICCT), The Climate and Clean Air Coalition and The World Bank Group
7. Vassallo, J., Asprea, H., Oficialdeguy O., Rodríguez Salemi V., y Gomez, B., Gomez, C.: Determination of aldehydes and ketones in exhaust emissions from EURO IV vehicles using mixtures of gasoline and bioethanol, in Argentina. Journal of the Argentine Association of Sanitary Engineering and Environmental Sciences (AIDIS) No. 125 (first quarter of 2015) pp. 53-62 